\title{
Hydrograph Study of Palu River Watershed
}

\author{
Yassir Arafat ${ }^{1 *}$, IG Tunas ${ }^{1}$, Tuty Amaliah ${ }^{1}$, and Aswar Amiruddin ${ }^{1}$ \\ ${ }^{1}$ Department of Civil Engineering, Tadulako University, Palu 94118, Indonesia
}

\begin{abstract}
Hydrograph is a way of predicting the amount of flood discharge plans in a watershed. Each watershed has different drainage characteristics due to the topographic shape of the watershed, land use, river typology (length, number, and slope), height and duration of rainfall. This research was conducted in Palu River Basin, with a basin area of $3.060,388 \mathrm{~km}^{2}$, mismatch analysis of watershed and synthetic unit hydrograph, rain and discharge analysis, hydrograph discharge design analysis using optimal synthetic unit hydrograph parameter model. From the results of research calculation of Synthetic Unit Hydrograph Nakayasu Method has big enough key compared with another method. By using hydrograph model of flood plan for Palu River Watershed with the approach of Synthetic Unit Hydrograph Nakayasu, hydrograph calculation of flood in Palu river watershed, obtained alpha coefficient equal to 0,651 and $\operatorname{Tr}$ coefficient 0,3 with cash value model $71,491 \%$.
\end{abstract}

\section{Introduction}

Rainfall in the tropical area have high spatial and temporal variability, where is influenced by the topography and climatological conditions in the watershed. Hydrograph theory is a way of predicting the amount of flood discharge plans in a watershed. Hydrograph is a graph showing the relationship between discharge and flood time. Planning water construction required analysis of estimation data of flood discharge. These estimates should be based on appropriate methods so as to produce flood estimates that are in line with the actual conditions. Each watershed has very different drainage characteristics that are influenced by several factors, including the topographic shape of watersheds, land use, river typology (length, number, and slope), height and duration of rainfall. Palu river basin with an area of $3.060,388 \mathrm{~km} 2$ is a large watershed in Central Sulawesi region[1] which administratively passes through Sigi, Donggala, and Palu districts so that accurate flood planning analysis is needed in this watershed area for planning, river improvement, and flood control. The results of research conducted by researchers in 2009 showed that of several methods of synthetic hydrograph unit calculation, Synthetic Unit Hydrograph Nakayasu method has a fairly large correlation coefficient of $0.80(80 \%)$ which means this method has a close enough relationship with the results of observation discharge flooding field[2].

*Corresponding author : iazzyr@gmail.com 
Next, on the River Basin Palu conducted a study model of flood discharge planning calculation with some model of synthetic unit hydrograph to obtain a fairly good accuracy value and close to field condition. Some parameters in the Nakayasu synthetic unit hydrograph method are made as dependent variables and independent variables.

\section{Literature Review}

In Indonesia several synthetic unit hydrograph models have been developed such as GAMA I, Limantara, ITS and ITB. The GAMA I Synthetic Hydrograph Model has a fairly good performance for watersheds in Java[3]. However, suggested that this model is used with extreme caution which can cause irregularities[4], because this model was built with the nature of the watershed in Java. Use outside of Java, especially in Central Sulawesi, the synthetic unit hydrograph model has also been widely applied for various purposes such as planning and research[5]. So far, the most widely used models are the Nakayasu and GAMA I Synthetic Unit Hydrograph Model. The test results of the two models on the two measured watersheds in Central Sulawesi show relatively low model performance. The Nakayasu Sintetic Hydrograph that was tested in the Kodina watershed showed significant deviations with values of $\mathrm{Tp}=26 \%$ and $\mathrm{Qp}=22.40 \%$ [6]. Likewise, the GAMA I Synthetic Hydrograph Unit tested in the Kodina watershed provides a deviation of $23.52 \%$, for the Tp parameter, $15.05 \%$ for the Qp parameter and $8.84 \%$ for the Tb parameter[7]. However, further research to optimize parameter structured has not been done much especially for watersheds in Central Sulawesi, including in the Palu watershed.

The hydrograph unit is derived from rainfall and base flow data by separating the base flow based on effective rainfall and the phi index $(\phi)$. Separation of the base flow is done using the straight-line method with the assumption that the base flow increases with time. Basic flow separation techniques in this way have been widely used by hydrological researchers such as [8], [4], [9], and other researchers with various arguments such as ease in identifying the end of base flow on the side of a hydrographic recession [10] .

Generally, design floods in Indonesia are determined based on the maximum daily rainfall analyses recorded. The maximum discharge frequency is rarely applied due to the limited observation period. To determine the flood discharge plan conducted flood peak flood analysis with several different methods ie:

1. Snyder synthetic unit hydrograph

2. Nakayasu synthetic unit hydrograph

\subsection{Snyder synthetic unit hydrograph}

The Snyder Synthetic Hydrograph Unit is a method commonly applied to produce direct runoff hydrographs in many water resource management applications [11]. Snyder synthetic unit hydrograph is determined fairly well with height $d=1 \mathrm{~cm}$ and with three other elements, ie $Q p$ (m3/ sec), $T b$ and $\operatorname{tr}$ (hours). 


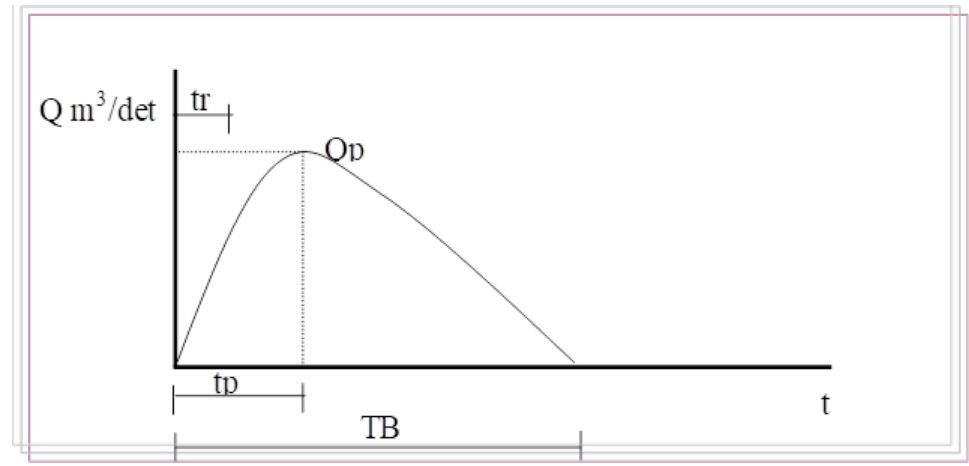

Fig. 1. Sketches of SYNTHETIC UNIT HYDROGRAPH Snyder-Alexeyev.

with the Snyder formula in equation (1), (2), (3) and (4):

$$
\begin{gathered}
t p=C t .(L . L C) 0.3 \\
t r=\frac{t p}{5.5} \\
O p=2.78 \mathrm{Cp} \cdot \frac{A}{t p} \\
T b=72+3 t p
\end{gathered}
$$

The coefficients $C t$ and $C p$ should be determined empirically because the values are different from one area to another.

\subsection{Nakayasu synthetic unit hydrograph}

In 1940 Nakayasu promoted synthetic hydrograph units based on research rivers in Japan, which until now were widely used and known as Nakayasu synthetic hydrograph units [12]. Flood hydrograph research using the Nakayasu synthetic unit hydrograph method was first carried out in Japan. The Nakayasu synthetic unit hydrograph is developed based on observations of natural unit hydrographs originating from a large number of watersheds in Japan. Based on the natural conditions in Japan which are hilly and rivers in Japan are relatively short with large slopes, the results of the calculation of time lag become smaller and the peaks are relatively sharp. In the calculation of discharge, starting from the up side to the down side, the calculation is done with different equations. With the $\alpha$ value that can be adjusted (trial error), so that peak discharge and hydrograph volume obtained can follow the shape of the observation hydrograph [13].

The Nakayasu synthetic unit hydrograph method in applications in 32 watersheds in Java, Indonesia, shows an average of $22 \%$ hydrograph form errors and $9 \%$ peak discharge errors [14]. Nakayasu from Japan has made a synthetic unit hydrograph formula from the results of his investigation. The formula shown in equation (5):

$$
O p=\frac{C X A X R_{0}}{3,6 \times\left(0,3 T p+T_{0,3}\right.}
$$

Where $\mathrm{Qp}=$ flood peak discharge $\left(\mathrm{m}^{3} / \mathrm{sec}\right), \mathrm{R}_{0}=$ rain unit $(\mathrm{mm}), \mathrm{Tp}=$ time lag from the beginning of the rain to the peak of the flood (hour). In this case if $\mathrm{L}>15 \mathrm{~km} ; \operatorname{tg}=0,21$. $\mathrm{L}^{\mathrm{ag}}$ and $\mathrm{L}<15 \mathrm{~km} ; \operatorname{tg}=0,4+0,058 \mathrm{~L}, \mathrm{~T}_{\mathrm{p}}=\operatorname{tg}+0,8 \mathrm{tr}, \mathrm{Tg}=$ time concentration (hours), $\mathrm{Tr}=$ time base of hydrograph $=0,5-1 \mathrm{tg}, T_{0,3}=\alpha . \operatorname{tg}$ 


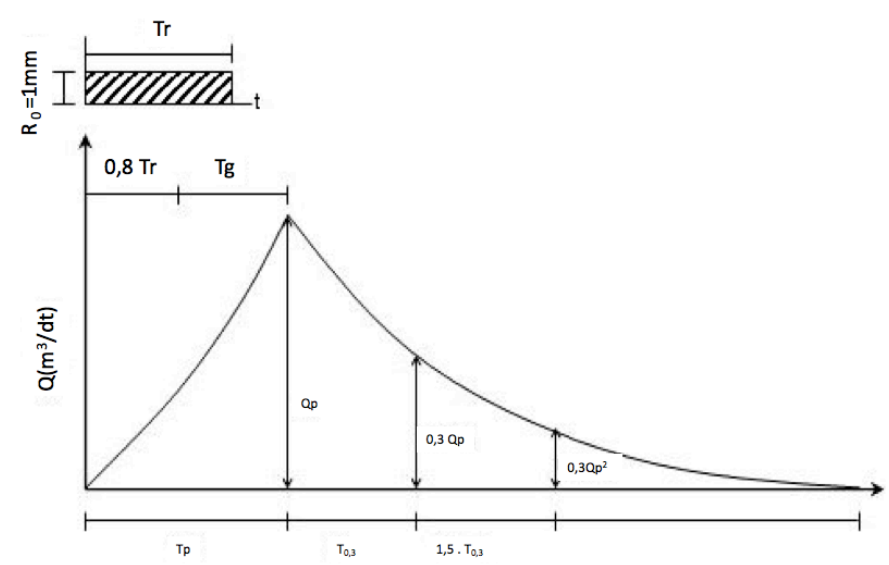

Fig. 2. Sketches of nakayasu synthetic unit hydrograph.

\section{Research Method}

This research is grouped into 4 (four) stages, preliminary study and data collection of both primary and secondary data, analysis of watershed morphometry and synthetic unit hydrographs, which serves to identify watershed parameters covering watershed area $(A)$, main river length $(L)$, river network density $(D)$, main river slope $(S)$ and other parameters related to model parameters used for analysis, rain and discharge analysis, then hydrograph analysis the design debit using the optimum Synthetic Unit Hydrograph model parameters to establish the amount of discharge that will be used for designing dry land irrigation dam in Palu River.

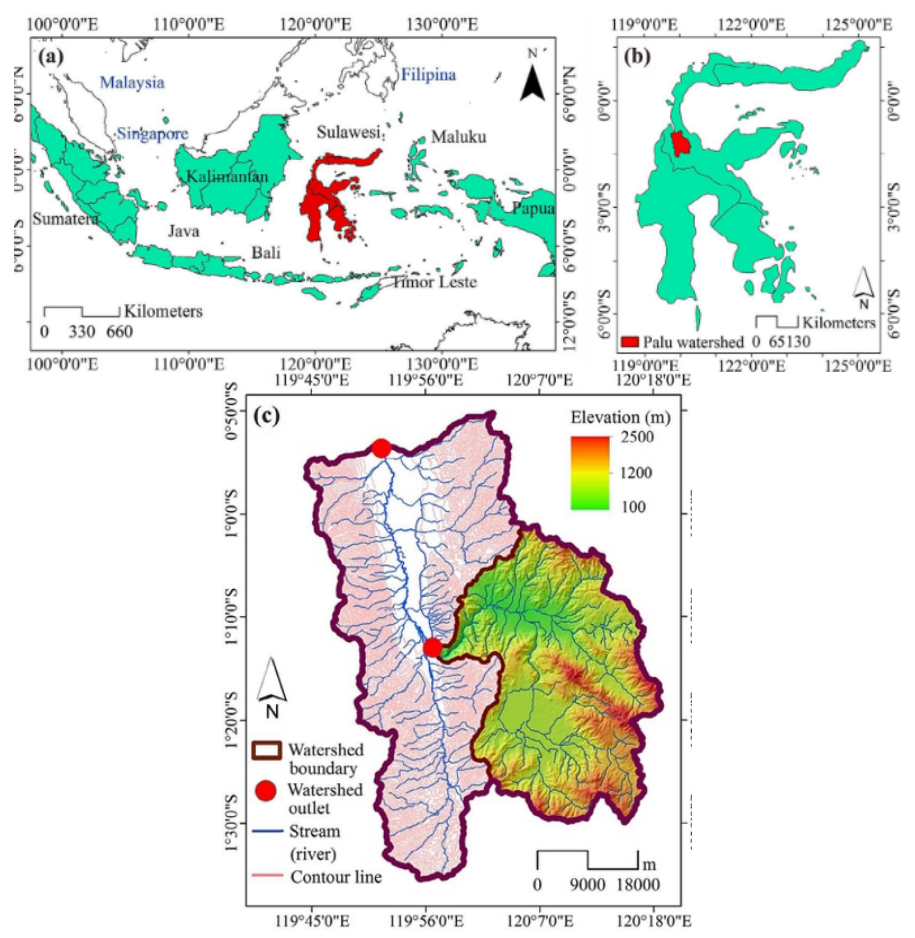

Fig. 3. Palu Watershed 


\section{Results and discussion}

The calculation of rainfall design is carried out on the maximum daily rainfall data from influential stations in the Palu basin. The results of the calculation of rainfall can be seen in the table and graph below:

Table 1. The return period of rainfall

\begin{tabular}{|c|c|}
\hline $\begin{array}{c}\text { Return Period } \\
\text { (Years) }\end{array}$ & $\begin{array}{c}\text { Rain Fall } \\
\text { (Mm) }\end{array}$ \\
\hline 2 & 27.873 \\
\hline 5 & 35.552 \\
\hline 10 & 40.369 \\
\hline 20 & 45.286 \\
\hline 25 & 46.340 \\
\hline 50 & 50.704 \\
\hline 100 & 54.947 \\
\hline
\end{tabular}
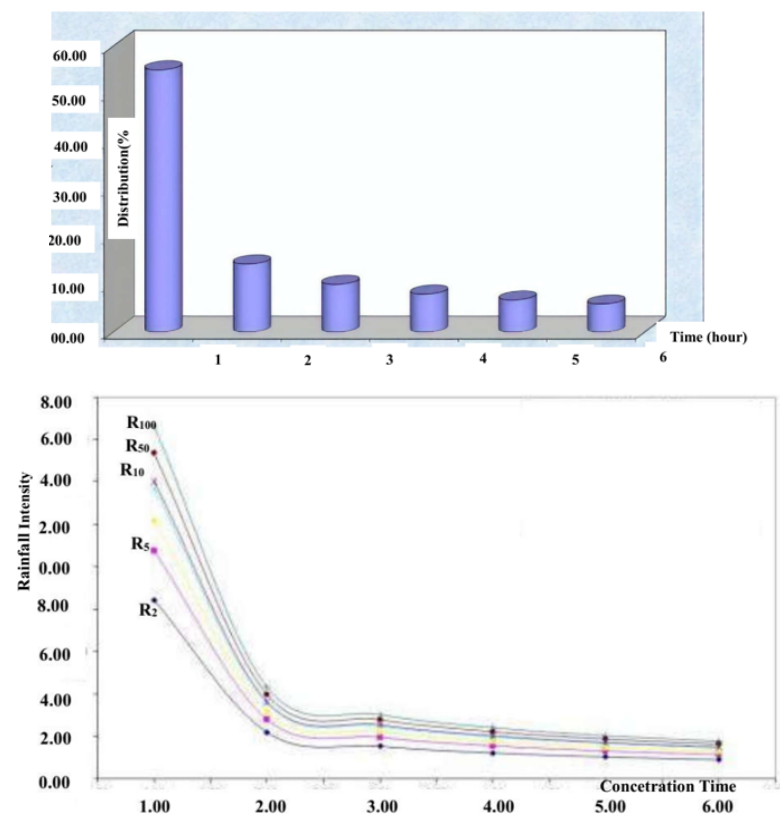

Fig 4. Hourly Rainfall Distribution and rainfall intensity

The Geomorphological Unit of hydrograph which includes the watershed structure in its formulation is based on the traditional concept which aims to connect the watershed response to a cascade of linear reservoirs. It should be noted that the watershed order (maximum order of the streams within the watershed) depends on the detail in which the drainage network is represented.

The runoff hydrograph for the river catchment based on the unit hydrograph obtained with Snyder-Alexejev synthetic presented in Fig. 5., while those obtained with Nakayasu synthetic unit hydrograph presented in Fig. 6. for adoption in the study area 


\subsection{Snyder-Alexejev synthetic unit hydrograph}

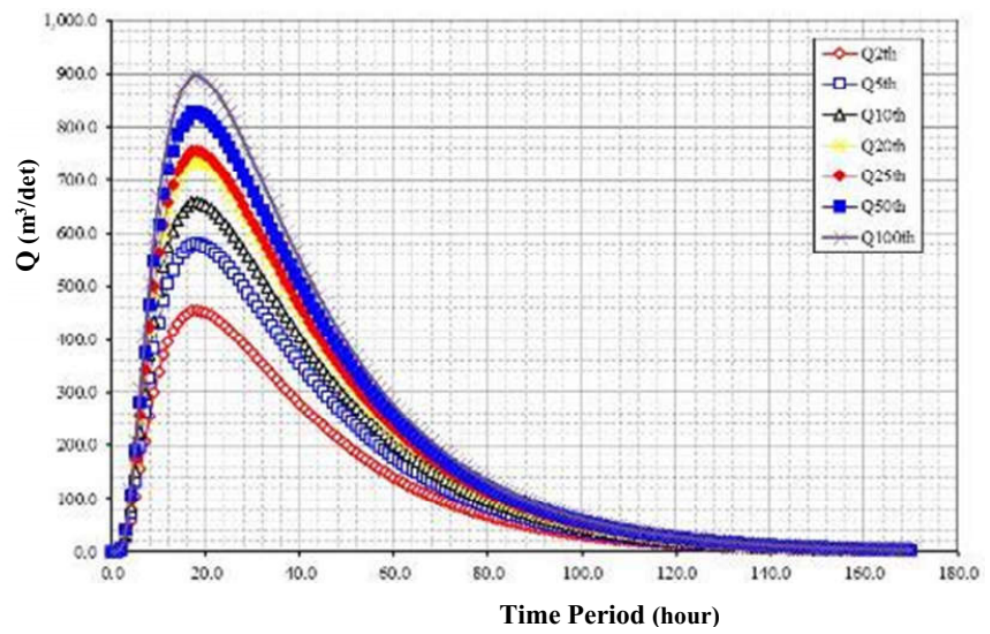

Fig. 5. Hydrographic Flow Design of Snyder-Alexejev Synthetic Unit Hydrograph Method (Synthetic Unit Hydrograph-Snyder-Alexejev)

\subsection{Nakayasu synthetic unit hydrograph}

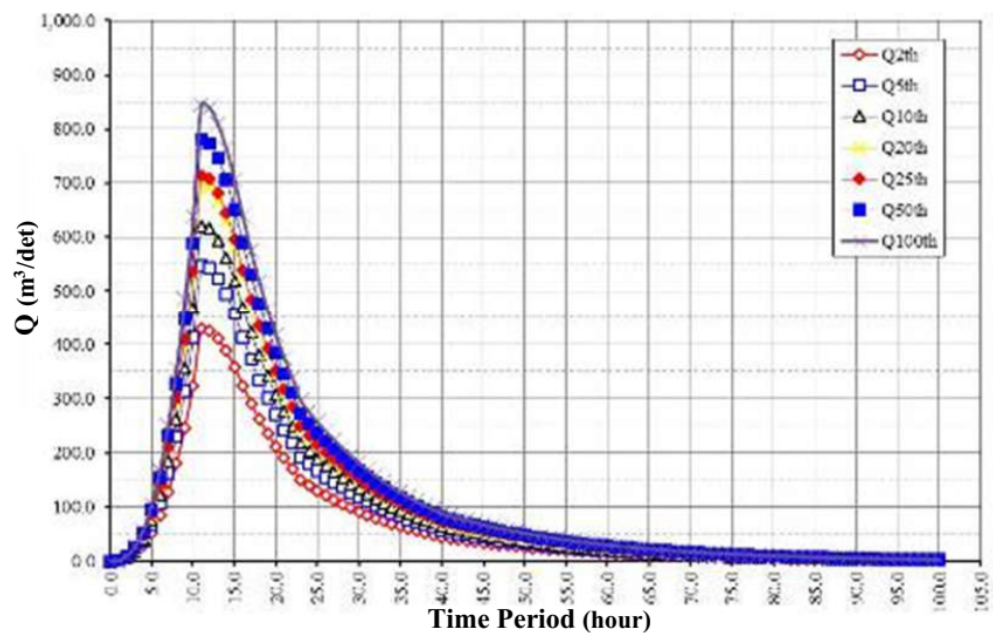

Fig. 6. Hydrographic Flow Design of Nakayasu Synthetic Unit Hydrograph Method (Synthetic Unit Hydrograph-Nakayasu)

Table 2. Flood discharge Palu river watershed

\begin{tabular}{|c|c|c|c|}
\hline \multirow{2}{*}{ No. } & \multirow{2}{*}{$\begin{array}{c}\text { Return Priod } \\
\text { (year) }\end{array}$} & $\begin{array}{c}\text { Fynthetic Unit } \\
\text { Hydrograph } \\
\text { Snyder }\end{array}$ & $\begin{array}{c}\text { Synthetic Unit } \\
\text { Hydrograph } \\
\text { Nakayasu }\end{array}$ \\
\hline 1 & 2 & 331.601 & 368.170 \\
\hline 2 & 5 & 411.833 & 459.050 \\
\hline 3 & 10 & 463.655 & 520.027 \\
\hline
\end{tabular}




\begin{tabular}{|c|c|c|c|}
\hline 4 & 20 & 516.855 & 584.327 \\
\hline 5 & 25 & 528.207 & 598.111 \\
\hline 6 & 50 & 575.738 & 657.386 \\
\hline 7 & 100 & 623.136 & 717.589 \\
\hline
\end{tabular}

Many factors can be analyzed from these results, the characteristics of the watershed area in addition to the possibility of influencing the reliability Nakayasu unit hydrograph, such as land use conditions which determine the nature of the runoff, found in both the peak discharge, as well as time to peak. Peak discharge coefficient $\mathrm{Cp}$ of Nakayasu is a factor that can correct this error through calibration, and modification. In the calculation Nakayasu unit hydrograph here, peak discharge coefficient is still original and has not been calibrated, so take $\mathrm{Cp}=0.98$.

Another factor is the time to peak. In Nakayasu method, the time to peak is fixed and the equation is a function of time of concentration and the main river length [15]. Changes in properties of runoff environmental changes in land use cannot be replaced through peak time because Nakayasu synthetic unit hydrograph does not give the peak time coefficient, so calibration is done through the coefficient of peak discharge, $\mathrm{Cp}$ only.

\section{Conclusion}

The runoff hydrograph for the Palu River Watershed, Central Sulawesi, Indonesia, has been analyzed in this study by using two methods of the synthetic unit hydrograph methods, i.e. the Snyder and Nakayasu. The watershed area is $3.060,388 \mathrm{~km}^{2}$, with the length of Main River $(L) 109.26 \mathrm{~km}$, used the coefficient of watershed characteristics $(\alpha) 1.68$ and Run Off (C) 0.37 .

In the calculation Nakayasu unit hydrograph, peak discharge coefficient is still original and has not been calibrated, so take $\mathrm{Cp}=0.98$. Another factor is the time to peak, the time to peak is fixed and the equation is a function of time of concentration and the main river lengt. By using hydrograph model of flood discharge design for Palu River Watershed with the approach of Synthetic Unit Hydrograph Nakayasu, hydrograph calculation of flood in Palu river watershed, obtained alpha coefficient equal to 0,651 and $\operatorname{Tr}$ coefficient 0,3 with cash value model $71,491 \%$

\section{Acknowledgment}

This research was funded by DIPA Engineering Faculty of Tadulako University No: SP DIPA042.01.1.400962 / 2018, March 9, 2018. I would also like to address many thanks to KDK Keairan, Civil Engineering Department of Tadulako University which has supported preparing this paper and The Balai Sungai Wilayah III Sulawesi has provided rainfall data in the Palu watershed.

\section{References}

1. O. Setiawan, Journal Penelit. Hutan dan Konserv. Lahan, vol. 3, no. 3, pp. 309-326, (2006).

2. A. W. Salami, International Egyptian Engineering Mathematical Society IEEMS," Zagazig Univ. Publ. Int. e-Journal Egypt., vol. 60, pp. 17-28, (2009).

3. D. K. Natakusumah, W. Hatmoko, and D. Harlan, J. Civ. Eng., vol. 18, no. 3, pp. 251291, (2011).

4. Sri Harto, Hidrograf Satuan Sintetik GAMA I. Jakarta: Badan Penerbit Pekerjaan Umum, (1985). 
5. I. G. Tunas, Institut Teknologi Sepuluh Nopember, (2017).

6. I. W. Sutapa, MEKTEK, vol. 7, no. 1, (2005).

7. V. W. Andiese, MEKTEK, vol. 14, no. 1, (2012).

8. K. Subramanya, "Engineering Hydrology. McGraw-Hill Education (India) Private Limited," New Delhi, (2013).

9. L. M. Limantara, Rekayasa Sipil, vol. 3, no. 3, pp. 209-226, (2012).

10. M. R. Khaleghi, V. Gholami, J. Ghodusi, and H. Hosseini, "Efficiency of the geomorphologic instantaneous unit hydrograph method in flood hydrograph simulation," Catena, vol. 87, no. 2, pp. 163-171, (2011).

11. L. W. Mays, Optimal control of hydrosystems. CRC Press, (2018).

12. M. Revel, D. Ikeshima, D. Yamazaki, and S. Kanae, Water, vol. 11, no. 4, p. 829, (2019).

13. Soemarto, Hidrologi Teknik. (1987).

14. A. B. Safarina, H. T. Salim, I. K. Hadihardaja, and M. S. Bk, Int. J. Civ. Environ. Eng. IJCEE-IJENS, vol. 11, no. 6, pp. 76-85, (2011).

15. S. Beskow et al., "Geomorphology-based unit hydrograph models for flood risk management: case study in Brazilian watersheds with contrasting physiographic characteristics," An. Acad. Bras. Cienc., vol. 90, no. 2, pp. 1873-1890, (2018). 